\title{
Between stress and tone in Nubi word prosody*
}

\section{Carlos Gussenhoven}

\author{
Radboud University Nijmegen and Queen Mary, \\ University of London
}

\begin{abstract}
Nubi is a language with culminative word prominence, spoken in Uganda and Kenya. The prominence, or accent, falls within a right-edge three-syllable window, and at the phrasal level deaccenting and rhythm-related accent shift occur in specific phonological and morphological contexts. Since accent is used to express morphological categories, and deaccenting and accent shift are morphologically conditioned, the functional load of accent is comparable to that of morphologically conditioned stress in other languages. Accented syllables are associated with $\mathrm{H}$ tones, with default $\mathrm{L}$ tones appearing between them. Typologically, Nubi is not a stress-accent language, because unlike for example English, it has no stress distinctions independently of the distinction between accented and unaccented syllables. It is also non-tonal, because accent marking is not lexically idiosyncratic, and because it has no option other than to supply a $\mathrm{H}$ tone in accented syllables, it is unlike a prototypical intonation language that has pitch accents with discoursal meanings.
\end{abstract}

\section{Introduction}

Nubi is a creole spoken by some 15,000 speakers in Uganda and some 10,000 in Kenya. It developed in the nineteenth century from an Arabic pidgin spoken by descendants of Emin Pasha's military personnel in southern Sudan and northern Uganda, and became separated from its lexifier language after 1885, when the Egyptian occupation of the Sudan came to an end as a result of the Mahdist revolt (Owens 1977, Wellens 2005). Some $90 \%$ of its vocabulary is from Arabic, and it has otherwise

\footnotetext{
* This work was made possible by the kind assistance and advice given by a number of people. I thank Ineke Wellens for facilitating my introduction to the Nubi community in Bombo, Abdul Majid Uthman for serving as my host and for his efficient help in recruiting speakers, Mustafa Khamis and Muzamil Ajobe for sharing their understanding of the language with me, and Abdullah Serwada for providing information on the wider Nubi community. I also thank my speakers Kifaya Musa, Salima Abdalla, Zena Rajab, Khadija Hamid, Abdul Majid Uthman, Abdulmajid Ibrahim Juma Kirchonaka, Kassim Hassan, Hawa Abdul, Osman Kassim and Farida Taib. I am grateful to Larry Hyman for extensive discussion, to him, Jörg Peters and Yiya Chen for their comments on an earlier version of the text and to Toni Rietveld for help with statistics.
} 


\section{Carlos Gussenhoven}

the character of a creole by having essentially the same tense-aspect system as Oceanic creoles (Owens 1980). The present description is based on the speech of the Ugandan Nubi community in Bombo, some 20 miles north of Kampala, who represent about half of the Nubi speakers in Uganda. Other Nubi-speaking localities are Kitubulu in Entebbe, Masindi in the west and Soroti and Jinja in the east of the country, while in Arua in north-eastern Uganda the language is associated with Islam and is also spoken by Muslims among the indigenous population. There is a strong cultural bond encompassing speakers in Uganda and Kenya, with Bombo serving as a centre. The phonology of the Kenya variety as spoken in Kibera, a suburb of Nairobi, has been described by Owens $(1977,1996)$ and Heine (1982), and the variety spoken in Mombasa by Luffin (2005). The Bombo variety is described by Wellens (2005).

An aspect of Nubi phonology that has remained unresolved is its word prosody and the putative role of lexical tone. While Owens (1977) characterises the language as having 'stress' or equivalently 'accent', Heine (1982) interprets it as having high and low lexical tone. He claims that tone is partly independent of stress, citing words with two high tones, only the first of which is stressed, such as /'lúgumá/ 'maize mush'. But since in many cases the $\mathrm{H}$ tones on unstressed syllables appear to be optional, he concedes that a description in terms of accent or stress might be possible. Wellens (2005) describes the Bombo variety as having both stress and tone. Intriguingly, she analyses the phonology of the morphological derivations of the verb in terms of stress shifts and tone changes which are independent of each other. On her account, Nubi is a tone language with movable stress which is independent of tone.

This paper has two goals. One is to set the record straight on the nature of the Nubi prosodic system. In addition, it argues that this system represents a significant case, in that it has properties that are widely seen as typical of three classes of languages that are often seen as distinct: tone languages, stress-accent languages and non-stress-accent languages (cf. Beckman 1986, van der Hulst 1999a, Hyman 2001, 2006). More precisely, Nubi can be argued either to escape categorisation as any of these language types or, depending on the interpretation of the criteria that have been applied, to be a tone language and a stress-accent language. At the same time, it can also be classified as a textbook case of Beckman's (1986) 'non-stress-accent' type, i.e. a language with pitch accent. Where Nubi differs from well-known cases of pitch-accent languages like Tokyo Japanese (Pierrehumbert \& Beckman 1988) and Northern Bizkaian Basque (Hualde et al. 2002) is in lacking a class of unaccented words.

A consideration of the Nubi system will allow us to sharpen up the definitions of some of these typological notions in significant ways. It will be argued (i) that Nubi cannot count as a typical tone language, since it has no lexically idiosyncratic pitch marking; (ii) that it cannot count as a language with stress accent, as its 'stress' would be equivalent to the presence of tone; and (iii) that it cannot count as a language with an intonation system, because even though tone is entirely postlexical 
(Kiparsky 1982), there is no freedom of choice among different tones to be inserted (barring a choice between $\mathrm{L}_{l}$ and $\mathrm{H}_{l}$ to signal the difference between statement and question intonation). If Nubi were the only language in the world, the terms 'tone', 'stress' and 'accent' would be synonymous.

$\S 2$ gives the basic phonology of Nubi, while the word prosody is treated in $\$ 3$, on the basis of the morphological derivations of the verb, and the postlexical prosodic phonology in $\S 4$. A summary is given in $\S 5$, in which the description is compared with that offered by Wellens (2005). Next, $\$ 6$ reviews some diagnostic criteria that have been used to characterise prosodic systems as belonging to language types like 'tone languages' and 'stress-accent languages', and applies them to Nubi. As a result, a reformulation of Beckman's (1986) criterion of the difference between 'stress accent' and 'pitch accent' will be offered, one that states the difference in structural rather than phonetic terms, while a more finegrained version of Hyman's (2001) definition of a tone language will be presented, one that excludes Nubi. I follow Hyman (2001, 2006) and Gussenhoven (2004: 41), in assuming that the notion 'non-stress accent', or equivalently 'pitch accent' in the non-Pierrehumbertian sense of one F0-related prominence per word, does not define a typologically coherent class of languages.

\section{Basic phonology}

This section presents the basic segmental and word prosodic facts. I will use the term 'accent', defined as a location for the insertion of a tone or tone sequence (Goldsmith 1976, Gussenhoven 1991, Hyman 2001) to refer to the word-prominent syllable of Nubi, rather than the term 'stress', defined as the head of a foot (Selkirk 1980).

\subsection{Segments}

Nubi has 21 consonants and five vowels, shown in (1). Loans from Arabic are frequent, and may contain one or more of the marginal consonants /q (k), $\theta(\mathrm{t}), \partial(\mathrm{d}), \mathrm{h}(\mathrm{h}), \mathrm{x}(\mathrm{h}) /$, where the bracketed consonant is the regular substitute for the preceding consonant in nativised pronunciations (Wellens 2005). ${ }^{1}$

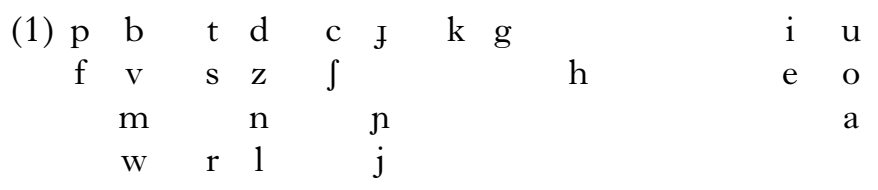

1 I will use IPA symbols as in (1). Nubi orthography generally follows Swahili spelling conventions. A revised orthography is currently being designed by Abdulmajid Ibrahim Juma Kirchonaka in Bombo. 


\section{Carlos Gussenhoven}

Syllable structure is $(\mathrm{C})(\mathrm{C}) \mathrm{V}(\mathrm{C})$, but $\mathrm{CC}$ clusters may occur wordfinally. All consonants can be initial; initial clusters are confined to /bw-, kw-, gw-, sk-, st-/. Coda consonants are infrequent generally. Among them, sonorants $(/ \mathrm{m}, \mathrm{n}, \mathrm{y}, \mathrm{r}, \mathrm{l} /)$ are the commonest, but $/ \mathrm{p}, \mathrm{t}, \mathrm{f}, \mathrm{s}, \int, \mathrm{w}, \mathrm{j} /$ also occur. Examples of word-final clusters are /-kt, -nt, -ns, -ms, -fs/. Wellens lists the final clusters /-jm, -js, jt, -wm/, which can arguably be reanalysed as single $\mathrm{C}$ codas after diphthongs. There are no quantity contrasts. $^{2}$

\subsection{Accent}

With the exception of verb stems, polysyllabic words are most frequently accented on the penultimate syllable, but words with antepenultimate accent and final accent are common.
(2) a. Jarára 'button'
d. carán 'sewing machine'
b. léjla 'night'
e. kisirán 'misfortune'
c. bágara 'cow'
f. nerekú 'child'

The generalisations governing the deletion or relocation of accents are both lexical, i.e. morphological, and postlexical, i.e. occur in particular word combinations. For instance, plurals of nouns have the accent on the last syllable, as shown in $(3 \mathrm{a}-\mathrm{c})$. Frequently, it is supplied by a plural suffix, of which $/-\mathrm{a} /$ is particularly common, as in $(3 \mathrm{~d}-\mathrm{g})$. The vowel coalescence shown in (3d) may vacuously be assumed to have occurred in $(3 \mathrm{~b}, \mathrm{c})$ as well.

\begin{tabular}{lll}
\multicolumn{1}{r}{ singular } & plural & \\
a. béle & belé & 'boy' \\
b. júa & juá & 'house' \\
c. bágara & bagará & 'cow' \\
d. búku & buká & 'book' \\
e. jál & jalá & 'child' \\
f. gumás & gumasá & 'garment' \\
g. cermán & cermaná & 'chairman'
\end{tabular}

\section{Verb forms}

The morphological use of accent is particularly apparent in the verb. There are three morphological classes, which, depending on the form of the stem, may differ by the position of their accent alone.

2 Geminates may have a marginal status. Wellens (2005: 51) mentions /állah/ 'God' and /jálla/ 'OK', as well as /ténna/ as a variant of /téna/ 'our'. 


\subsection{The stem}

Stems (called 'bare forms' by Wellens 2005) have the usual three positions for the accent, as shown in (4). Type (4a), a trisyllable ending in [u] and with initial accent, is by far the most common, and it may be argued that $[\mathrm{u}]$ is a verbal suffix which is not counted when accent is assigned to stems (Kees Versteegh, personal communication; see also note 3 below). The accent may occur on the penult, as in (4b) (cf. also /arína/ 'return'), although the number of such verbs is small; trisyllabic stems with the accent on the final syllable do not exist. However, there is a small class of verbal adjectives (e.g. (4c)), some of which are trisyllabic and have final accent, as in (4f) (cf. also /sakarán/ 'be drunk', /haragán/ 'be sweaty'). These refer to non-permanent physical and mental characteristics, and when used as predicates, resemble stative verbs (Wellens $2005: 67$ ). The same forms can also be used transitively, in which case they are causatives. Vowel-final disyllables typically have the accent on the penult, as in (4d), but there are a handful of disyllabic verbs that have it on the last syllable, as shown in (4e).

$\begin{array}{llll}\text { (4) a. kásulu } & \text { 'wash' } & \text { e. wedí } & \text { 'give' } \\ \text { b. nesítu } & \text { 'forget' } & \text { f. tabán } & \text { 'be/make angry' } \\ \text { c. fatarán } & \text { 'be/make tired' } & \text { g. só } & \text { 'do' } \\ \text { d. fáta } & \text { 'open' } & \text { h. gúm } & \text { 'get up' }\end{array}$

The Nubi accent pattern can be described by assuming a syllabic trochee at the right edge of the word, plus lexical specification of feet to account for exceptional antepenultimate and final accent. A formal analysis will be dispensed with here, as it does not bear directly on the issue at hand. However, it is relevant to observe that the distribution of accent, falling as it does in a three-syllable window, can be described metrically, whether in a parametric framework (e.g. Halle \& Vergnaud 1987, Hayes 1995) or in an OT version (Kager 1999).

Accents that survive on the surface are provided with $\mathrm{H}$. No other tone options are possible. The falling contour in (5) can be attributed to the accentual $\mathrm{H}$ and a final boundary $\mathrm{L}_{l}$, while an initial $\mathrm{L}_{l}$ can be used to describe the low pitch with which utterances begin, as shown in (5). (The initial boundary tone in (5a) is likely to be truncated for lack of segmental space. A description of a similar case of initial truncation is given by Bruce (1977); cf. Gussenhoven (2004: 168).) The only tone that is negotiable is final $\mathrm{L}_{l}$, which may be replaced with $\mathrm{H}_{l}$ to express a different discoursal meaning.

(5) a.

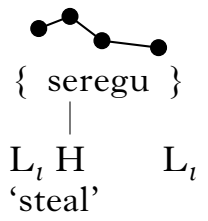

b.

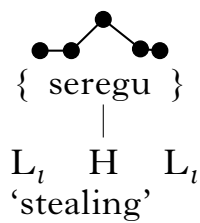

c.

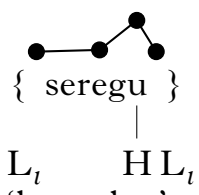

'be stolen' 


\subsection{The gerund}

The gerunds of (4) are given in (6). They are identical to the stems, except for the-very frequent-group of verbs with antepenultimate stress, which appear with penultimate accent in the gerund.

(6)
a. kasúlu 'washing'
e. wedí
'giving'
b. nesítu
'forgetting'
f. tabán
'being angry'
c. fatarán
g. só
'doing'
d. fáta
'being tired'
h. gúm
'getting up'

Gerund formation involves the suffixation of a 'floating' trochee, given in (7).

\section{(7) Gerund}

$(\mathrm{x} \cdot)]$

The retention of the final accent in (6e) suggests that faithfulness to the foot structures of the stem here prevents the accent from being relocated to the penult, while the loss of the underlying stem accent on the first syllable of (6a) suggests that the rightmost accent survives. Conceptually, the suffixation is similar to that of a right-aligning floating feature [-back] in diminutive formation in German, where the last full vowel of the stem in fronted, as in Kopp 'cup'-Köppchen 'cup (DIM)'. In (8), the suffixation is illustrated for stems with antepenultimate accent, final accent and penultimate accent. The first column lists the underlying forms of all morphemes. In (8a) and (8b), the antepenultimate and final foot-heads of stems are lexically marked, but no underlying prosodic structure exists for words with penultimate accent in (8c). The second column shows how the suffixal foot is added to the stem, but with the preservation of the lexical foot-heads in (8a) and (8b), since existing structure is respected. As also shown in this column, all foot-heads are accented. Thus in $(8 \mathrm{~b})$, the first syllable is a foot-head due to the gerund suffix, while the second syllable is a foot-head due to its lexical marking; in (8a), the first syllable is lexically marked as a foot-head, and the second syllable is a foothead due to the gerund suffix. In the third column, regular footing is provided, with parsing of all syllables, and non-rightmost accents are deleted. ${ }^{3}$

3 An alternative suggested by Larry Hyman is to assume extrametrical final syllables in words with antepenultimate accent and zero-derivation of the gerund. By disallowing extrametricality inside a derived form, the effect of the derivation is deletion of the extrametricality marking: kasul $<u>\rightarrow[$ kasul $<u>] \rightarrow[$ kasulu $]$. Default penultimate accent follows. Final accented words must be pre-marked, which accent is preserved in derived forms, much as in $(8 \mathrm{~b})$. 


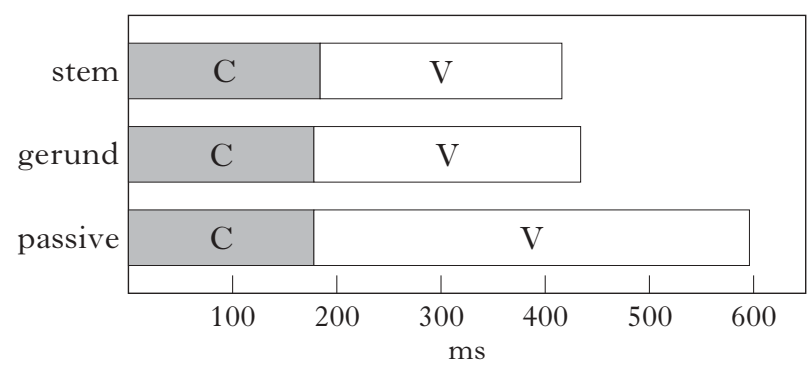

Figure 1

Mean consonant and vowel durations of the stem, gerund and passive of /łá/ 'arrive' and /só/ 'do', spoken in isolation by speakers KM, OK and ZR.

(8)

$\begin{array}{llll}\text { stem }+ \text { gerund } & \begin{array}{l}\text { affixation, } \\ \text { accent }\end{array} & \begin{array}{l}\text { footing, } \\ \text { rightmost }\end{array} & \\ \text { a. }(\mathrm{x} \cdot) \cdot]+(\mathrm{x} \cdot)] & (\dot{\mathrm{x}})(\dot{\mathrm{x}} \cdot)] & (\mathrm{x})(\dot{\mathrm{x}} \cdot)] & / \text { kasúlu/ } \\ \text { b. } \cdot(\mathrm{x})]+(\mathrm{x} \cdot)] & (\dot{\mathrm{x}})(\dot{\mathrm{x}})] & (\mathrm{x})(\dot{\mathrm{x}})] & / \text { wedíl } \\ \text { c. } \quad \cdots \cdot[+(\mathrm{x} \cdot)] & \cdot(\dot{\mathrm{x}} \cdot)] & (\mathrm{x})(\dot{\mathrm{x}} \cdot)] & / \text { nesítu/ }\end{array}$

\subsection{The passive}

Passives have the accent on a final open syllable. Verbs that end in a consonant acquire a final vowel to carry the accent, like / cék-cekí/ 'check', /nákam-nakamá/ 'confiscate' (Wellens 2005: 177), /tabán-tabaní/ 'irritate', /gúm-gumú/ 'get up'. As the last example shows, the language has impersonal passives, as in /gí gumú/ 'people are getting up'. The vowel is typically a copy of the last vowel of the stem. ${ }^{4}$ Thus, relative to the stem and the gerund, the accent has shifted to the last syllable in (9a, b, d), while an accented vowel has been added in $(9 c, f, h)$.

(9)
a. kasulú 'washed'
e. wedí
'given'
b. nesitú
'forgotten'
f. tabaní
'angered'
c. fataraní
g. so.ó
'done'
d. fatá
'made tired'
h. gumú
'got up (IMPERS PASS)'

As shown in $(9 \mathrm{~g})$, stems that consist of a single open syllable acquire a copy of their vowel. Besides /só/ 'do', which the passive /so.ó/, we find / já/ 'arrive', with the passive/ja.á/. The duration of the doubled vowel is around $70 \%$ longer than that of the gerund and stem, as shown in Fig. 1, which gives mean durations of the consonant and vowel in three

4 One case of a vowel different from the last vowel in the stem is the / $\mathrm{i} /$ added to verbal adjectives ending in /an/. A correlation between high front vowels and coronal consonants has been attested in a number of languages, and forms one of the arguments for a common feature analysis for consonants and vowels. See in particular Clements (1993), which directly expresses the correlations concerned. However, the data do not allow for any generalisations. 

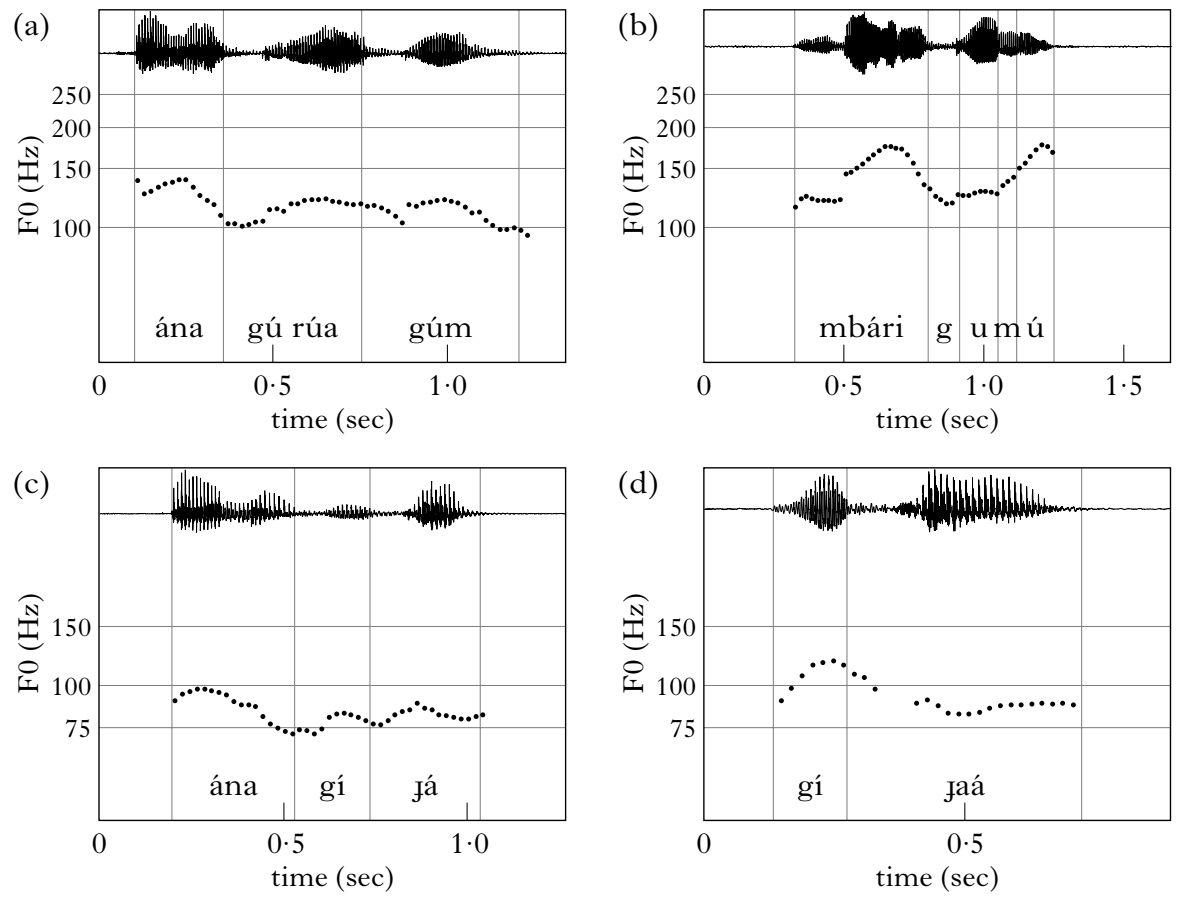

Figure 2

Waveforms and F0 tracks of (a) /ána gú rúa gúm/ 'I'm getting up' and (b) /mbári gumú/ 'Yesterday people got up' (speaker OK), and of (c) /ána gí Jál 'I'm coming' and (d) /gí łaá/ 'People are coming' (speaker AU).

morphological forms of / já/ and /só/, spoken in isolation (for data recording and analysis details, see Appendix). A repeated-measures analysis on vowel duration with Morphological Class and Word as factors showed a significant main effect for Morphological Class only, $\mathrm{F}(1 \cdot 007,2)=9 \cdot 18$. Tukey's test for Homogeneous Subsets revealed that the passive is significantly different from both the stem $(p=0.01)$ and the gerund $(p<0.05)$ and that the difference between stem and gerund is insignificant. The doubled vowels form single smooth stretches of voicing, but are structurally disyllabic, as is apparent from the rise-fall-rise contour in the passive. This is consistent with the presence of a $\mathrm{H}$ on the second syllable, assuming the first syllable does not have a $\mathrm{H}$ tone (see also $\$ 4.3$ ), while being inconsistent with the assumption of a monosyllable, in which case the initial low pitch and late peak become hard to explain. Figure 2 compares monosyllabic stems ((a) and (c)) with their passive counterparts ((b) and (d)), showing a closed syllable in (a) and an open syllable in (c). The pitch range of speaker AU is fairly narrow, but the rise in the second part of the syllable can clearly be seen.

The passive of disyllabic verbs with final accented open syllables (cf. $(9 \mathrm{e})$ ) is homophonous with the stem and gerund. Figure 3 gives mean 
(a)

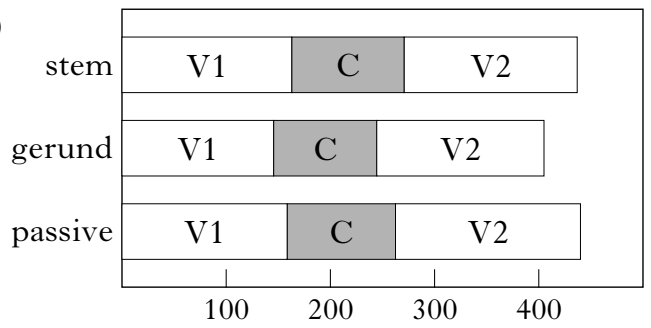

(b)

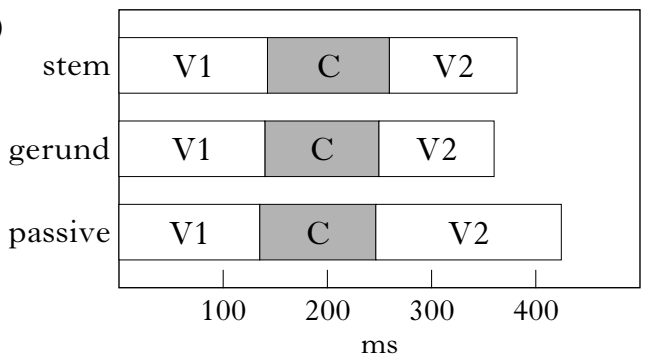

Figure 3

Mean vowel and intervocalic consonant durations of the stem, gerund and passive of (a)/nadí/, /wedí/ and (b) /fáta/, / sídu/, as spoken in isolation by speakers FT, KM, OK and ZR.

durations of the VCV in /nadí/ and / wedí/ spoken in isolation (a), showing absence of lengthening of the final syllable in the passive, as might be expected if they worked like/s.ó/. Some lengthening of the second vowel (V2) of the passive can be observed in (b), which could be attributed to the difference in accentuation between stems and gerunds /fáta/,/sídu/ on the one hand and the passives /fatá/,/sidú/ on the other. However, a repeatedmeasures analysis on V2 duration, with Morphological Class and Word as factors, revealed only a trend for Word $(\mathrm{F}(1 \cdot 95,5 \cdot 85)=3 \cdot 75, \mathrm{p}<0 \cdot 10)$. The pitch measurements of V1 and V2 in the same pronunciations show homophony of the passive with the stem and gerund in the case of /nadi/, /wedí/, as is evident from Fig. 4. It shows means of the mean Equivalent Rectangular Bandwidth (ERB) values of V1 and V2 of the stem, gerund and passive. ${ }^{5}$ By contrast, the mean ERB values for the vowels in the passives /fatá/ and /sidú/ contrast with those of the stems and gerunds /fáta/ and /sídu/, while stems and gerunds are homophonous. Separate repeated-measures analyses of variance on the ERB values of V1 and V2, with Word and Morphological class as factors, revealed significant interactions between Word and Morphological class for both vowels (V1: $\mathrm{F}(6,18)=3 \cdot 98 ; \mathrm{V} 2: \mathrm{F}(6,18)=3 \cdot 15)$, as expected. This result is clearly due

${ }^{5}$ Because the speakers have different pitch ranges, ERB values have been used in this comparison, as they reflect linguistic pitch better than $\mathrm{Hz}$ values (Hermes \& van Gestel 1991). 


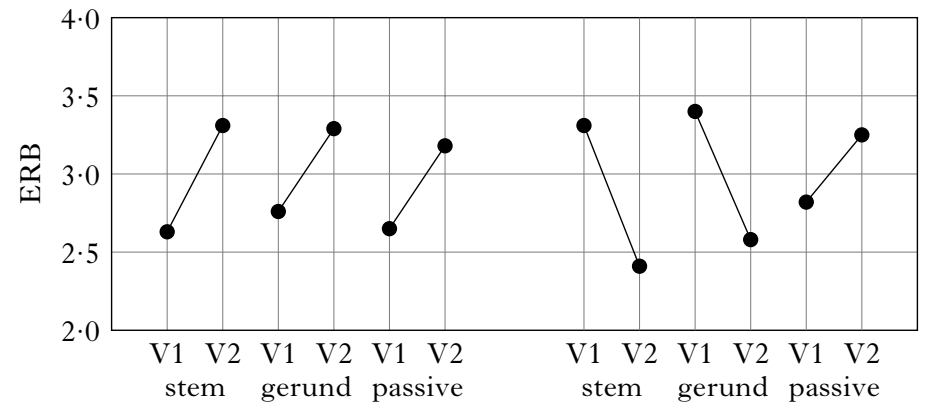

Figure 4

Mean ERB values of the first and second vowels of the stem, gerund and passive of (left) /nadi/, /wedi/ and (right) /fáta/, /sídu/, as spoken in isolation by speakers FT, KM, OK and ZR.
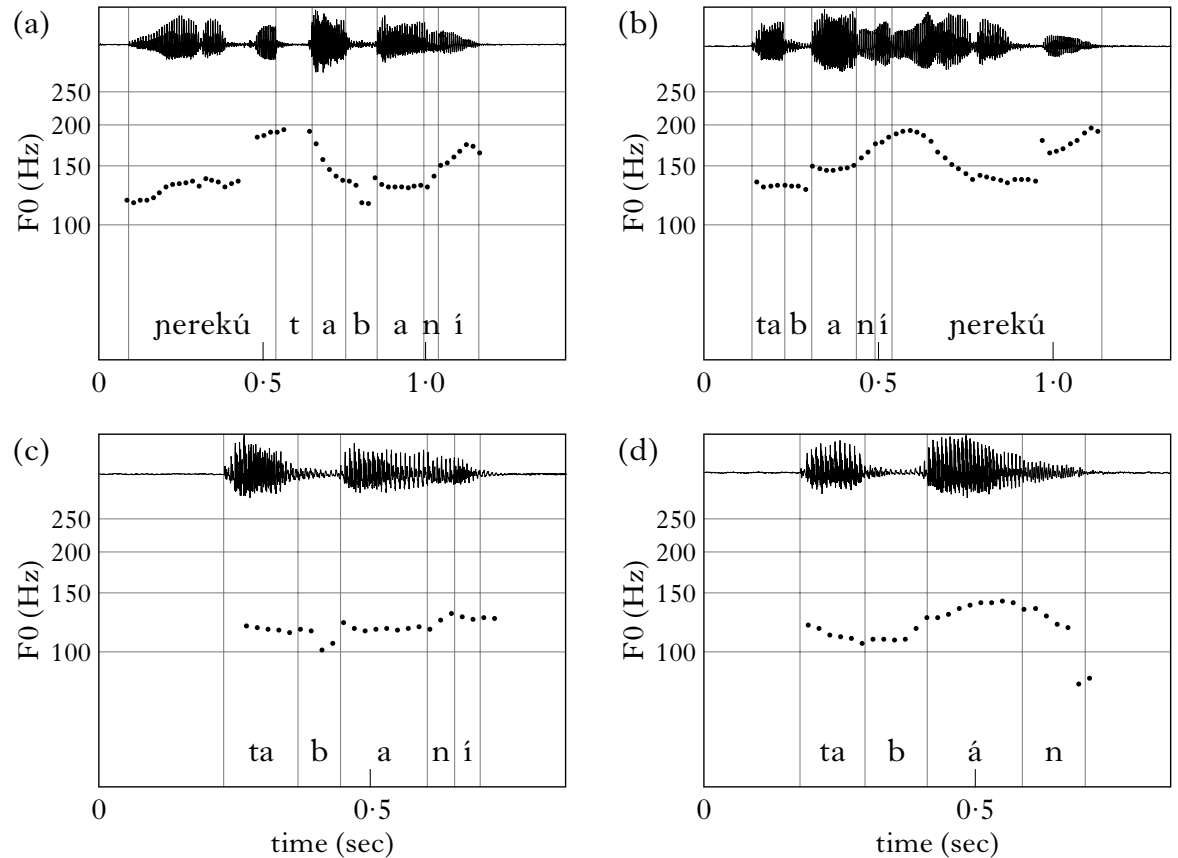

Figure 5

Waveforms and F0 tracks of (a)/nerekú tabaní/ 'The child is being irritated', (b) / tabaní nerekú/ 'The child is being irritated', (c) /tabaní/ 'being irritated' and (d)/tabán/ 'irritating' (speaker OK). 
to the dependence of vowel pitch in the stem and gerund on the word, as shown in Fig. $4{ }^{6}$

The generalisation that can be made is that the passive ends in an accented vowel, as expressed in (10). The suffix is attached in like manner to that of the gerund in (8).

(10) Passive

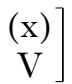

Earlier descriptions of the Nubi passive are not fully in agreement with the one offered here. Owens (1977) observes for the Kibera variety that the passive has final stress, but does not mention the extra vowel, except in the case of $(9 \mathrm{~g})$. Even for this form, however, there is disagreement. Unlike our findings (cf. Fig. 1), Owens states that the lengthened form is also used for the gerund. The final vowel in /tabaní/ is illustrated in representative contours in Fig. $5 \mathrm{a}-\mathrm{c}$, in final position, non-final position and in citation pronunciation. Figure $5 \mathrm{c}$ is representative of the kind of pronunciation in which the final short vowel of the passive is not salient. In this instance, the $/ \mathrm{i} /$ is brief and nasalised, and might conceivably be interpreted as voiced release of the nasal. However, in many other instances, both sentence-final (a) and sentence-internal (b), the vowel is clearly audible. The contour in (c) should also be compared with that of the gerund in (d), which has final accent, but no added vowel. Finally, Wellens (2005:24) refers to the passive form as having extra strong final stress. This impression can in part be explained by an interpretation, incorrect in my view, of the long phonetic vowel in CV.V as a single syllable. The late pitch peak in $(9 \mathrm{~g})$ may sound 'insistent' to speakers of intonational languages. For the Mombasa variety, Luffin (2005) gives no information on the phonological forms of passives, observing merely that the morphological use of accent in the verb is marginal.

A question that will remain unanswered here is why the passive shouldn't be just*/só/, given that the passive of /wedí/ is homophonous with the stem and gerund. The stem vowel should be able to satisfy the $\dot{V}$ of the suffix in both cases. The form cannot be explained on the basis of a constraint on the minimal size of words, like the foot. First, forms like /so.ó/ are not trochees, and thus not single feet, assuming Nubi is trochaic. Second, monomoraic words abound, and there is no indication that minimal wordhood is otherwise relevant.

\section{Phrasal phonology}

There are two generalisations above the word level affecting the accentuation of verbs. The first concerns a deaccenting rule applying to

6 There were main effects of Word in both cases $(\mathrm{V} 1: \mathrm{F}(2 \cdot 74,8 \cdot 21)=12 \cdot 87$; V2: $\mathrm{F}(3,9)=7 \cdot 88)$ and of Morphological Class in the case of $\mathrm{V} 1(\mathrm{~F}(2,6)=5 \cdot 53)$. 


\section{Carlos Gussenhoven}

nominalised verbs in pre-object position. The second is a rule of Accent Shift, applying to adjectives before their heads.

\subsection{A deaccenting rule}

In addition to the gerund as presented in $\$ 3.2$, Wellens (2005) recognises an 'infinitive', described as a form that has $\mathrm{H}$ tones before as well as on the stressed syllable. The postulation of an infinitive is unnecessary for two reasons. First, the syntactic contexts in which the two forms occur are complementary. The gerund is described by Wellens as occurring without an object or with an object that is preceded by the preposition /ta/ 'of'. Some of her examples are reproduced in (11). By contrast, the infinitive invariably appears in combination with an object, without an intervening preposition. Arguably, instead of looking upon this form as constituting a morphological class, we are dealing with the effects of phrasal phonology. ${ }^{7}$

(11) a. ína gén fi alábu

1PL stay PREP play+GER

'We continued playing.' (Wellens 2005: example 513b)

b. abídu ta kalám au abídu ta sokól

begin + GER GEN problem or begin+GER GEN thing

'the beginning of a problem or the beginning of something'

(Wellens 2005: example 520)

Second, in languages generally it is not uncommon for verbs to have reduced prominence in relation to their objects. English, German and Dutch deaccent predicates in combination with arguments, as illustrated in (12a) (Gussenhoven 1983, 1992, Selkirk 1984, 1995), and Basque reduces the pitch range of final verbs in phrasal enclitics, shown in (12b), where ( ) indicates an Accentual Phrase and \{\} an Intonational Phrase (Elordieta 1997). A rule deaccenting verbs that occur together with their objects is therefore not unexpected.

(12) a. Ich habe GELD gestolen

'I have stolen money.'

b. $\{$ (Amaiak dirua) emon nau $\}$

Amaia+NOM money give AUX

'Amaia has given me the money.'

Impressionistically, Nubi infinitives have low or mid level pitch throughout their duration. The infinitive form of /seregu/ is compared with the gerund in Fig. 6. The F0 track corresponding to the infinitive

7 Wellens attempts to attach different meanings to the gerund and the infinitive, by associating the gerund with results of actions or events and the infinitive with the actions or events themselves, but this difference does not appear to cover the distinctions between the two forms. It would appear to be comparable to that between English the chopping of wood and wood chopping. 
Between stress and tone in Nubi word prosody 205
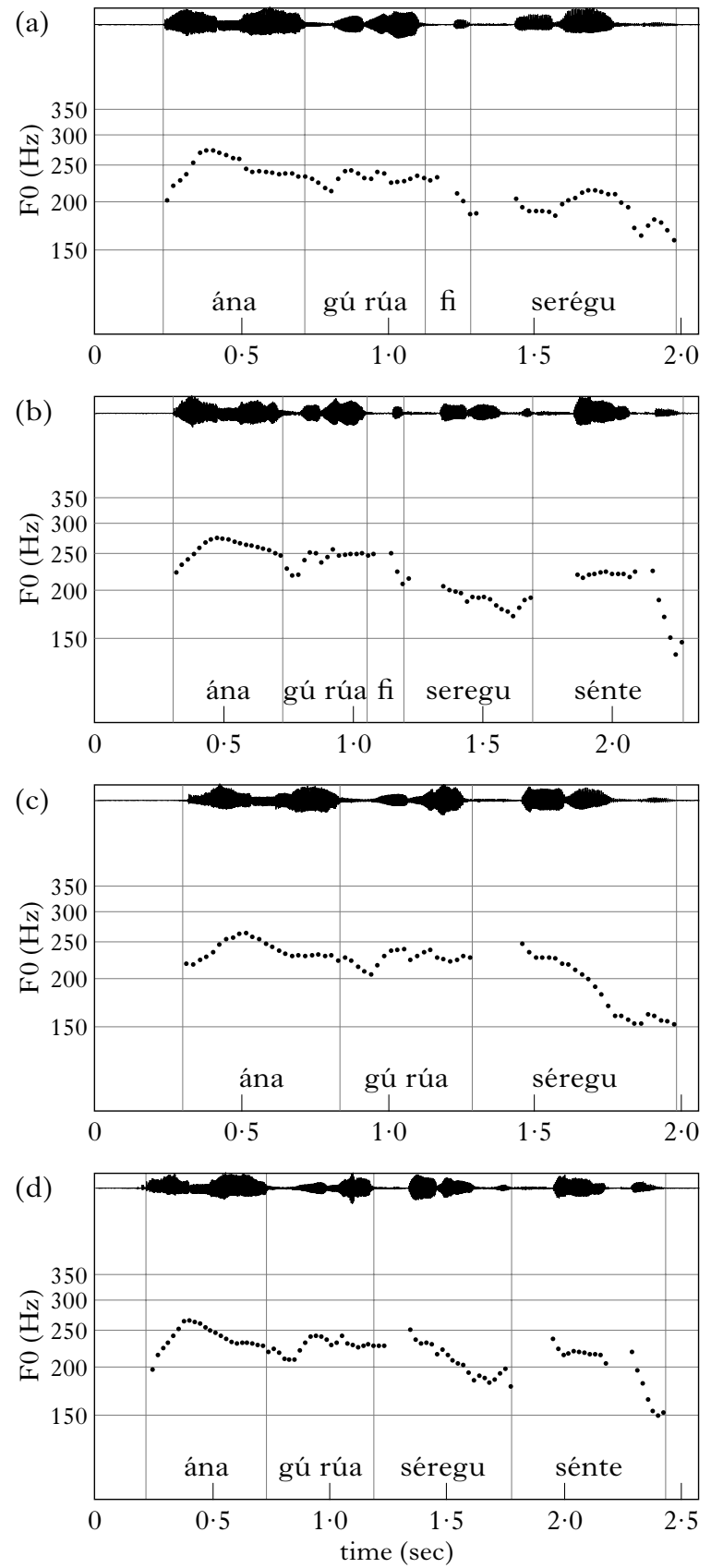

Figure 6

Waveforms and F0 tracks of (a) /ána gú rúa fi serégu/ 'I will be stealing', (b) /ána gú rúa fi seregu sénte/ 'I will be stealing money', (c) /ána gú rúa séregu/ 'I'm going to steal' and (d) /ána gú rúa séregu sénte/ 'I'm going to steal money' (speaker ZR). 
/seregu/ in (b) can first be compared with that of the gerund / serégu/ in (a), where there is no following object. ${ }^{8}$ The contour in (b) does show a falling trend, while the last syllable has a weak rise, but these movements represent transitions from the higher $\mathrm{F} 0$ on the surrounding words. To show this phonetic nature of the initial transitional fall in /seregu/ in (b), a comparison must be made with the phonologically induce fall in the stem /séregu/ in (d), which occurs in a similar context but starts from a high level. In final position, the initial phonologically induced fall of the stem can again be seen in (c), where it contrasts with the later peak of the gerund in (a). I conclude that Wellens' infinitive is a deaccented gerund, caused by Gerund Deaccenting (13).

\section{(13) Gerund Deaccenting}

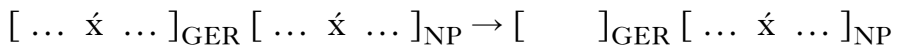

In many languages, deaccenting leaves stress behind, as it does in English. That is, English deaccenting is non-neutralising, since a phonological distinction exists between unstressed and unaccented stressed syllables, as shown by the final syllables of raider /'reidə(r)/ and radar |'reIda:(r)/. In Southern British English (14a), with its final unstressed $\mid-$ miz/, is distinct from $(14 b, c)$.
(14) a. I didn't SAY 'Hermy's'.
b. I didn't SAY 'Hermes'.
c. I didn't SAY 'Burmese'.

In fact, a further distinction exists between unaccented primary stressed syllables, as in (14c), and unaccented secondary stressed syllables, as in (14b), causing English to have a three-way contrast among unaccented syllables (cf. Gussenhoven 2004: ch. 2). Deaccenting in Nubi has a neutralising effect. For instance, for a number of speakers /pángisa/ 'to rent (to someone)' forms a minimal pair with/pangísa/ 'to rent (from someone)', as illustrated in Fig. 7a, b. The utterance in (c), which has a deaccented gerund in first position, is ambiguous to speakers who make the distinction, and could mean either 'Renting a house to someone is not good' or 'Renting a house from someone is not good'.

Syllable durations in deaccented words are predominantly like those of accented words. Figure 8 gives mean syllable durations for one speaker over four trisyllabic words for each of their four possible prosodic forms, as spoken in a position before the direct object or, in the case of the passive, before the subject. As can be seen by comparing the top and bottom bars, the durational structure of the deaccented gerund is virtually identical to that of the stem, and very similar to that of the

8 The complex auxiliary /gú rúa/ consists of /gú/, which like /í/ marks the progressive, and /rúa/ 'go'. It is pronounced [gurwa], [grwa], with high pitch throughout. 
Between stress and tone in Nubi word prosody 207
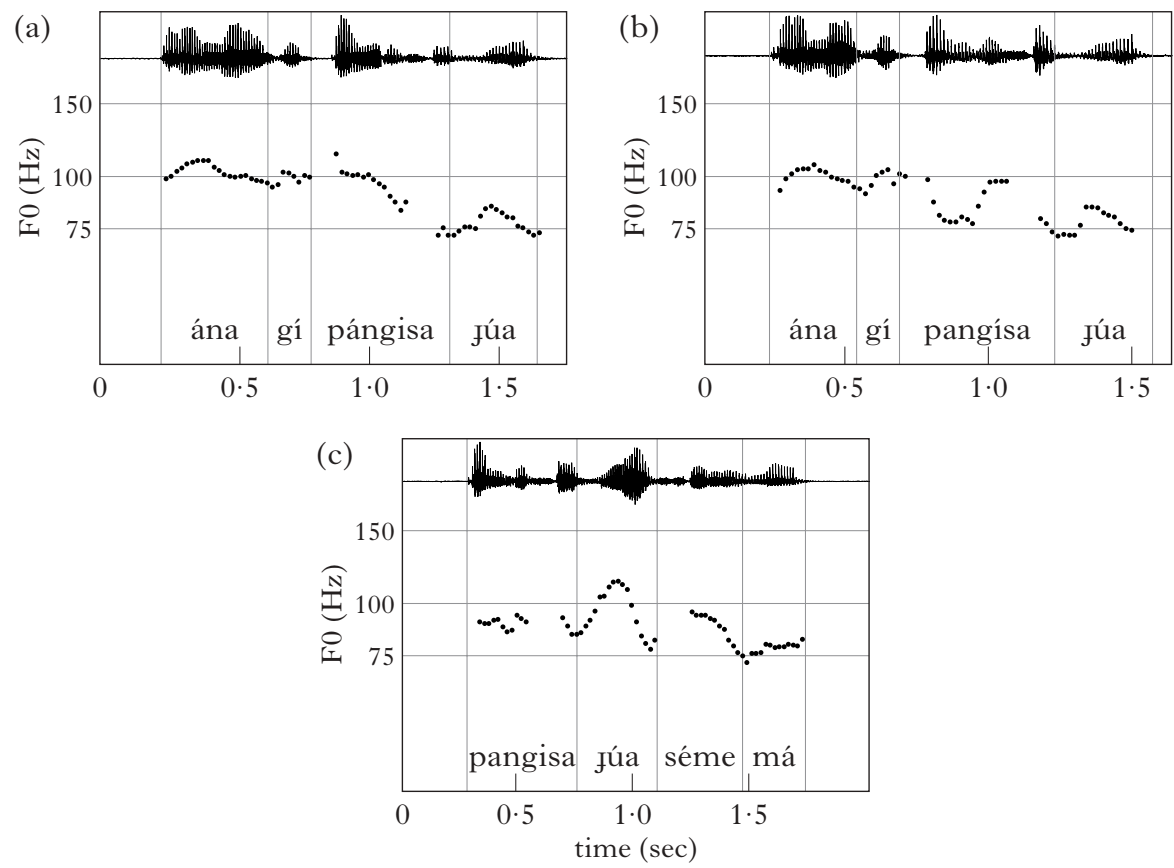

Figure 7

Waveforms and F0 tracks of (a) /ána gí pángisa fúa/ 'I’m renting a house to someone', (b) /ána gí pangísa júa/ 'I'm renting a house from someone' and (c)/pangisa fúa séma má/ 'Renting a house to/from someone is not good' (speaker AU).

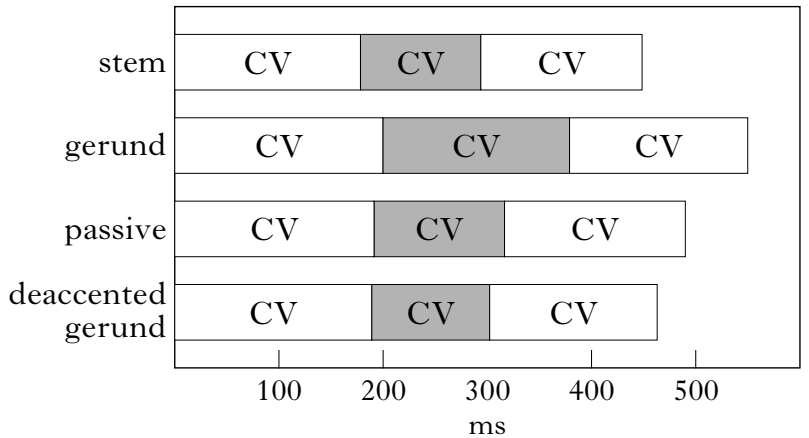

Figure 8

Mean syllable durations of the stem (CVCVCV), gerund (CVCV́CV), passive (CVCVCV́) and deaccented gerund (CVCVCV) of / beredu/, / kasulu/, /seregu/ and /pangisa/, as spoken in sentence-internal position by speaker OK. 
passive. ${ }^{9}$ Only the accented penultimate syllable in the gerund is clearly longer than its unaccented counterparts in the other forms, but for initial and final syllables no real difference is observed. Although a difference was also found between accented and unaccented final syllables in disyllabic words, we see in Fig. 8 - using the terminology of CambierLangeveld \& Turk (1999) - that neither word-initial nor word-final lengthening is additive with respect to accentual lengthening in trisyllabic words, causing only the medial syllable to show the effect of accentual lengthening.

Incidentally, the predictability of accent does not mean that the functional load of accent is low. For instance, because Gerund Deaccenting does not apply to passives or stems, deaccenting functions as a parsing cue to the NP formed by a gerund and its object. Conversely, an accent on a verb indicates that it heads a VP. That is, /séme/ 'good' in (15a), which contains the passive form /kasulú/ 'be washed', cannot be parsed as a predicate (*'It is good that the garment is washed'), a role which is taken by /kasulú/. Likewise, in (15b), /séme/ must be an adverb. Both examples contrast with the gerund in $(15 \mathrm{c})$, in which / séme/ must be parsed as a predicate if the expression is to be a sentence.
a. kasulú gumás séme wash+PAss garment good 'The garment has been properly washed.'
b. kásulu gumás séme 'Wash the garment properly!'
c. kasulu gumás séme
'Washing a garment is good.'

\subsection{A rhythm rule: Accent Shift}

In addition to falling within a three-syllable window, there is one more feature of the Nubi accent which indicates its metrical nature. Clash resolution is a widely reported tendency for languages to avoid adjacent prominent elements and to create distance between them. The prominent elements are either stresses, i.e. foot-heads, or accents. English has a rule that creates Phonological Phrases in which initial and final accents occur in preference to medial ones (Liberman \& Prince 1977, Selkirk 1984, Nespor \& Vogel 1986, Gussenhoven 1991). This is illustrated in (16).

$$
{ }_{\phi}(\text { stríctly Latin Américan })_{\phi} \sim{ }_{\phi}(\text { Látin American músic })_{\phi}
$$

9 The passive is longer than the stem and the unaccented gerund, because it occurs in a different phonological phrase from the following subject, while stem and gerund occur in the same phonological phrase as their objects, causing pre-boundary lengthening to be apparent in the passive. The prosodic phrasing follows a common pattern of syntax-phonology mapping whereby syntactic phrases align with prosodic phrases (Selkirk 1986, 2000). 

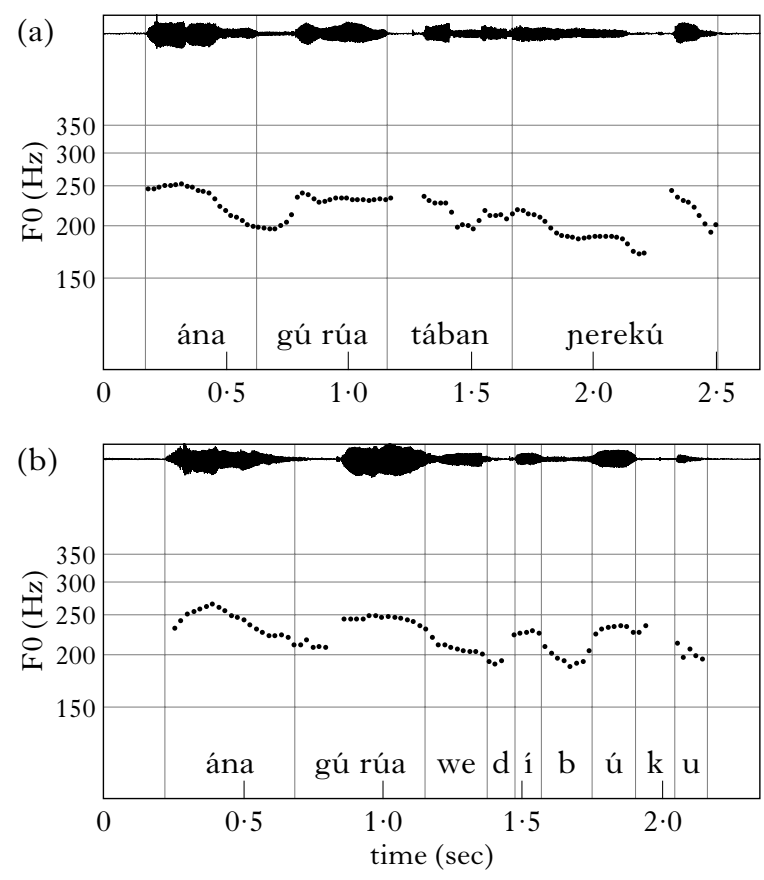

Figure 9

Waveforms and F0 tracks of (a) /ána gú rúa tában nerekú/ 'I will irritate the child' and (b) /ána gú rúa wedí búku/ 'I will give a book' (speaker FT).

Nubi has a similar rule, which locates the accent on the first syllable of verbal adjectives if they precede the direct object, which probably means that the domain is the phonological phrase. Wellens $(2005: 107)$ points out that, like other adjectives but unlike verbs, adjectival verbs may take plural endings, as in /zalimín/ 'unfair' (cf. the singular/zalím/). However, unlike other adjectives, they can take verbal morphology as well, as shown for the passive of /tabán/ in Fig. 5a-c. A second feature they share with adjectives, but not with verbs, is that they undergo Accent Shift.

\section{(17) Accent Shift}

Align the left edge of a phrase containing an adjective and its head with an accent.

Since adjectives follow the noun, with or without an intervening conjunction, the phenomenon may be infrequent, which may explain why it is not mentioned by Owens (1977), Luffin (2005) or Wellens (2005). An example of a plain adjective undergoing Accent Shift is given in (18a) (cf. (18b)). It can be interpreted as a left-edge alignment of accent and a (syntactic or prosodic) phrase containing an adjective preceding its head, as expressed in (17). 
(18) a. ána kesím

'I'm foolish.'

b. késim ána

'What a fool I am!'

Examples (19a, b) show Accent Shift in the adjectival verb/tabán/. It is obligatory and does not depend on the distance between the accents. That is, it applies in the same way in (19a), where the underlying accent of /tabán/ is separated by two syllables from the next accent, as it does in (19b), where the underlying accents are adjacent. Example (19a), illustrated in Fig. 9a, can be compared with (19c), in which a real verb precedes the object /búku/. (In Fig. 9b, the stretch of speech from [i] to [u] is heard as continuous high level pitch; the dip in the contour at [b] is a local consonantal perturbation.)

$$
\begin{aligned}
& \text { a. ána gú rúa tában nerekú } \\
& \text { 1sG will irritate child } \\
& \text { 'I will irritate the child.' } \\
& \text { b. ána gí tában tóru } \\
& \text { 1sG PRoG irritate bull } \\
& \text { 'I'm irritating the bull.' } \\
& \text { c. ána gú rúa wedí búku } \\
& \text { 1sG will give book } \\
& \text { 'I will give a book.' }
\end{aligned}
$$

Accent Shift is compared with Gerund Deaccenting in Fig. 10 for the verbal adjective/fatarán/ 'to irritate'. In (a), the second peak in the contour is on /fá/. The unaccented pronunciation is shown in (b), in combination with the same word/nerekú/. Speaker AU produced a downstepped contour in (a). Downstep is a frequent, though not obligatory, manner of realising second and subsequent peaks, contrary to the suggestion of Heine (1982), who observed that there is always downstep in declarative sentences.

\subsection{Default $L$}

The sentence prosody is completed with default $\mathrm{L}$ tones. While default L-tone insertion is a frequent phenomenon in African tone languages, these tones are typically associated. In Nubi, there is no evidence for or against association of the $\mathrm{L}$, while there is positive evidence that it does not spread. Unless the distance between the peaks is some four syllables or more, a slowly falling contour is observed. Since its slope appears to depend on the distance between the accents, it reveals what has been seen as the hallmark of interpolation between high and low targets (Pierrehumbert \& Beckman 1988). The tendency is to create a low target before the peak, leaving the pitch to fall gradually from the preceding peak, as in the case of the two inserted $\mathrm{L}$ tones in (20a), the representation 

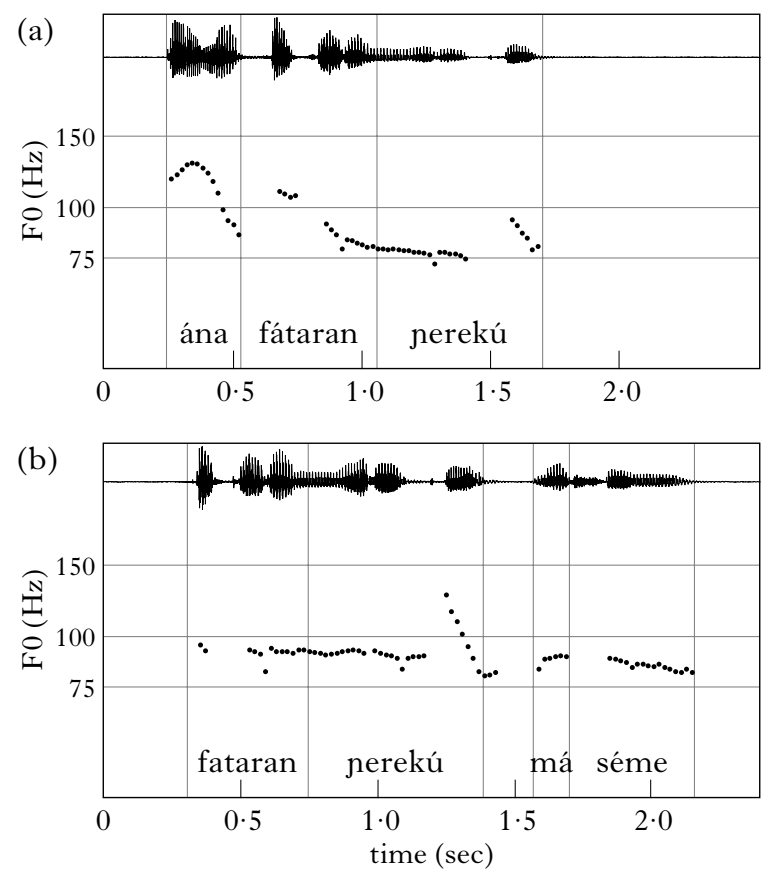

Figure 10

Waveforms and F0 tracks of (a) /ána fátaran nerekú/ 'I'm irritating the child' and (b) /fataran nerekú má séme/ 'It is not good to irritate a child' (speaker AU).

of the contour in Fig. 6a. Unaccented /fi/ may be compared with the high pitch of accented auxiliary verb /gí/ in (20b), in which three valleys occur. ${ }^{10}$

(20) a.

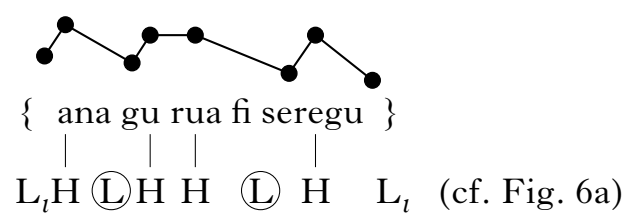

b.

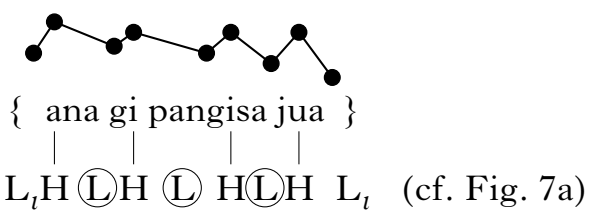

10 The fact that some classes of function words are accented and some are not might provide some motivation for classifying Nubi as a tone language. However, because of the metrically determined location of accent, an analysis whereby certain function words do not have word status, and hence do not acquire independent footing, seems more appropriate. 


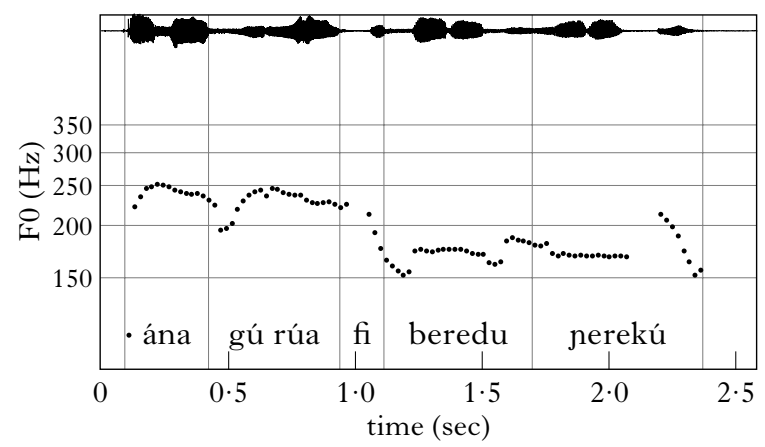

Figure 11

Waveform and F0 track of /ána gú rúa fi beredu nerekú/

'I will be giving a bath to the child' (speaker FT).

At the beginning of longer interaccentual stretches, a lefthand low target will appear, creating level low pitch. I assume that the default $\mathrm{L}$ tone is aligned with the $\mathrm{H}$ tone on its right, producing a target before it, and that when the distance between peaks is longer, the $\mathrm{L}$ tone also aligns left, producing an additional target immediately after the preceding $\mathrm{H}$ tone. Simultaneous left-alignment is indicated by means of the arrow in (21), the representation of the contour in Fig. 11 (cf. Gussenhoven 2004: ch. 7 for the double alignment of tones). Low-level unaccented stretches also occur at the beginning of sentences, in particular those beginning with deaccented gerunds, as in the contour in Fig. 10b.

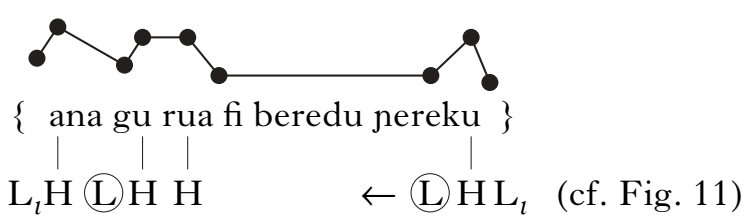

\section{Summary of Nubi word prosody}

The aim of the description above was to clarify the nature of Nubi word prosodic structure. Ignoring some classes of function words, all words are accented, accent is assigned in the verbal morphology so as to overrule the lexical location, deaccenting occurs in gerunds before their objects and accent is initial in phrases with premodifying adjectives. The description in Wellens (2005), summarised in Table I, claims that the verb forms dealt with in $\S 3$ are distinguished by differences in tone as well as both stress level and stress location. While stress and $\mathrm{H}$ tone usually co-occur in her analysis, Wellens postulates an infinitive with $\mathrm{H}$ tones before the stress, while also claiming the existence of extra high 


\begin{tabular}{|c|c|c|c|}
\hline & trisyllabic & disyllabic & monosyllabic \\
\hline & kásulu & fáta & só \\
stem & 'HLL & 'HL & 'L \\
gerund & L'HL & 'HL & 'L \\
infinitive & 'HHL & 'HH & 'H \\
passive & LL'H & L'H & 'H \\
\hline & nesítu & wedí & \\
stem & L'HL & L'H & \\
gerund & L'HL & L'H & \\
infinitive & H'HL & H'H & \\
passive & LL'H & L'H & \\
\hline & fatarán & & \\
stem & LL'H & & \\
gerund & LL'H & & \\
infinitive & HH'H & & \\
passive & LL'H & & \\
\hline
\end{tabular}

Table I

Phonological representations of Nubi verb forms according to Wellens (2005: 54-55), after her Table 8. Tones occurring in stressed syllables are represented as ' $\mathrm{H}$ and ' $\mathrm{L}$; bold represents extra stress.

tone-cum-stress in final syllables of passives. It is suggested here that the impression of pre-stress H-tone in infinitives is due to Gerund Deaccentuation, applying to gerunds before their objects, and that there is no case to be made for a separate morphological class of infinitives. Second, Wellens' impression of extra stress in passives is probably due to the addition of a vowel to the right edge of the word, which in particular in cases like/so.ó/ 'being done' creates the impression of an emphatic pronunciation of the monosyllabic gerund or stem. Table II gives the phonological representations of the words in Table I according to the description offered in this article. Notice that I have argued for a feature that is typical of stress-accent languages, Accent Shift, a process that is akin to the rhythm rules (or stress-shift rules) of many European languages. This adds an extra line at the end of Table II.

\section{Typological criteria}

This section considers the significance of Nubi for the typology of word prosody. It does so by considering the extent to which the language exploits the three functions of pitch in its word and sentence prosody: to 


\begin{tabular}{|c|c|c|c|}
\hline & trisyllabic & disyllabic & monosyllabic \\
\hline stem & kásulu & fáta & só \\
gerund & kasúlu & fáta & só \\
infinitive & kasulu & fata & so \\
passive & kasulú & fatá & so.ó \\
\hline stem & nesítu & wedí & \\
gerund & nesítu & wedí & \\
infinitive & nesitu & wedi & \\
passive & nesitú & wedí & \\
\hline stem & fatarán & & \\
gerund & fatarán & & \\
infinitive & fataran & & \\
passive & fataraní & & \\
accent shift & fátaran & & \\
\hline
\end{tabular}

Table II

Phonological representations of Nubi verb forms according to the present description.

distinguish words from one another $(\S 6.1)$, to mark stressed syllables $(\S 6.2)$ and to express phrasing and information structure $(\S 6.3)$.

\subsection{Tone}

On the basis of Hyman's definition in (22), the class of tone languages includes not just languages with dense tonal specifications, such as many Sino-Tibetan languages and languages spoken in sub-Saharan Africa, but also languages with sparse lexical tone, like Swedish, Norwegian and Japanese.

(22) A language with tone is one in which an indication of pitch enters into the lexical realisation of at least some morphemes (Hyman 2001: 1367, 2006).

The definition in (22) makes Nubi a tone language, since all major class words and many function words have an accent in the lexical representation, in the sense of a location for the insertion of a tone. However, there is an important difference between languages that are typically cited as 'accentual' tone languages and Nubi. 'Accentual' tone languages typically have at least one lexically idiosyncratic aspect in the way words are marked for pitch. Restricting ourselves to prosodic systems with a single accent per morphological or phonological word-the culminative systems of Hyman (2006) - there are three ways in which the accent can be lexically 
idiosyncratic. (Recall from $\S 2$ that by 'accent' I mean an insertion marker for tone.)

(i) There may be an unpredictable group of unaccented words, as is the case in Basque (Elordieta 1998, Hualde 1999, Hualde et al. 2002) and Japanese (Pierrehumbert \& Beckman 1988, Kubozono 1993, Poser 2001). Equally, under privative analyses of the binary opposition between Accent 1 and Accent 2 in Norwegian (Kristoffersen 2000) or in Central Franconian dialects (e.g. Gussenhoven \& Peters 2004), the group of words without an indication of tone is 'unaccented' in this sense. In Nubi, all words are accented in the lexical representation, and there is therefore no lexical idiosyncrasy in the presence or absence of accent.

(ii) The location of the accent in the word may be lexically idiosyncratic. For instance, in Gernika Basque the accent can fall on any syllable except the last (Hualde et al. 2002), while in Swedish, it coincides with the main word stress. Languages like Swedish, in which the position of the accent is metrically defined, are said to have 'metrically bound accent' by Hermans (1985). The important point is that in metrically bound accent languages, which are very common, the location of the accent is to be accounted for metrically, as in Halle \& Vergnaud (1987) and Hayes (1995). The location of the accent may be unpredictable only to the extent that the location of the stress is unpredictable. This is comparable to Spanish, which is analysed in the literature as obeying a three-syllable window, whereby penultimate accent in vowel-final words and final accent in consonant-final words is phonologically derived, but other accent positions are morphologically determined. For a recent treatment, see Roca (2005).

(iii) There may be a paradigmatic choice for the tone to be inserted in the accented position. In Basque, only one tone choice exists: $\mathrm{H}^{*} \mathrm{~L}$. In Barasana, there are two options, $\mathrm{H}$ and HL, and the choice is lexically determined (Gomez-Imbert \& Kenstowicz 2000). Similarly, in Kaure, either $\mathrm{H}$ or HL can be inserted in the stressed syllable of a word, again a distinction that needs to be indicated in the lexical specification (Donohue 1997). The multi-tone option may be restricted to a particular stress location, as it is in Ma'ya, where there a lexically determined choice from $\mathrm{H}, \mathrm{LH}$ or no tone, but only if the stress is final. Thus Ma'ya has lexically idiosyncratic unaccented words, i.e. words with final stress that take no tone, a lexically idiosyncratic choice of tone, i.e. $\mathrm{H}$ or $\mathrm{LH}$, but predictable accent location, i.e. final stressed syllables (Remijsen 2002). In Nubi, it is always $H$ that is placed on accented syllables.

Since Nubi fails all three lexically idiosyncratic aspects of pitch marking, it cannot really count as a tone language, other than by conforming to (22). To exclude Nubi, we could restrict (22) to languages in which either the identity of the morphemes or the specific pitch feature specified or the location of the pitch feature in the morpheme would otherwise be unpredictable from other features in the phonological representation, like the location of the stress. 


\section{Carlos Gussenhoven}

\subsection{Stress}

An implication of a metrical definition of the accent location is that the phonological element that is accented is the syllable, stress being a property of syllables (Hayes 1995). Languages that place accent on the mora, like Somali (Hyman 1981) and Safwa (Voorhoeve 1973), are not 'metrically bound', since an instruction to place accent in the stressed syllable leaves the location of the accent unspecified in long stressed syllables. Nubi has metrically bound accent, placing it on syllables. While the location of the accent is unpredictable in the sense that a word may have accent on the antepenult, the penult or the final syllable, these locations fall within a three-syllable window, and are to be described metrically (cf. §8), rather than by arbitrary lexical marking of the accent. However, while falling within the definition of a stress-accent language given by Hyman (2006), reproduced in (23), Nubi is not a typical stressaccent language.

(23) A language with stress accent is one in which there is an indication of word-level metrical structure meeting the following two central criteria:

a. OBLIGATORINESs: every lexical word has at least one syllable marked for the highest degree of metrical prominence (primary stress);

b. Culminativity: every lexical word has at most one syllable marked for the highest degree of metrical prominence.

A distinction between 'stress-accent languages' and 'non-stress accent languages' (or equivalently 'pitch-accent languages') was drawn by Beckman (1986: 1) as in (24).

(24) Stress accent differs phonetically from non-stress accent in that it uses to a greater extent material other than pitch (Beckman 1986).

Whereas the most prominent syllable in a word in English is longer than other syllables and has a less reduced vowel, in addition to being marked with tone in focused pronunciation, Beckman (1986) shows that the accented syllable of a Japanese word stands out virtually exclusively because it is associated with pitch features. Beckman's distinction hinges on the phonetic realisation of prominent syllables within the word (Ladd 1996: 156). Among the wider set of typological criteria, (24) is unusual in being gradient rather than discrete. It accordingly allows some latitude in judging the extent to which pitch features are accompanied by other phonetic features before the language can properly be said to have 'stress accent' rather than 'non-stress accent' (or 'pitch accent'). For instance, Levi's investigation (2005) of Turkish minimal pairs like /gazóz-la/ 'with soda' - /gazoz-dá/ 'in soda' as spoken in brief carrier sentences revealed significant differences in intensity and duration between accented syllables and their otherwise equivalent unaccented counterparts, but the F0 differences were considerably more salient. In a Discriminant Analysis, 
duration performed just above chance, while intensity explained $70 \%$ of the difference between stressed and unstressed syllables. However, F0 alone accounted for $90 \%$, and because of this relative importance of the pitch differences, Levi argues - rightly or wrongly - that Turkish is a pitch-accent language in the sense of Beckman (1986). Findings similar to those for Turkish, with differences in duration and intensity occurring alongside differences in pitch, have been reported for a number of languages (Berinstein 1979, de Jong \& Zawaydeh 1999, Dogil \& Williams 1999). ${ }^{11}$ It may thus be difficult to determine across a wider group of languages where exactly the cut-off point between pitch accent and stress accent should lie.

A discrete interpretation of Beckman's distinction, one which is in keeping with the spirit of (24), is possible if the question is answered whether deletion of accent or, equivalently, of the tone(s) inserted in that position leaves behind a syllable that is prosodically distinct from an otherwise equivalent syllable that never had accent. If it does, it makes sense to speak of stress as something distinct from accent. This interpretation of Beckman's criterion is given in (25).

(25) A language has stress if unaccented syllables come in minimally two prosodic (metrical) types.

According to (25), which is offered as an alternative to both (23) and (24), English is a stress language, because it has prominence distinctions that are independent of the presence of accent. By contrast, Polish is neutralising according to Dogil \& Williams (1999: 309), who find that unlike German and Lithuanian, 'word stress in Polish does not have any specific phonetic parameters which may separate it from the phonetic realization of the intonational structure', and 'manifests itself phonetically only if it is also a designated position for a pitch-accent'.

There are two reasons why the answer to the question whether a language has neutralising deaccenting may not be determinable. One is that there may not be any postlexical rules that deaccent syllables, as appears to be the case in Egyptian Arabic (Hellmuth 2005) and Spanish (Iggy Roca, personal communication). In such cases, deaccenting is exclusively a fast-speech phenomenon, making it hard to set up the appropriate comparison between a deaccented and an accented condition, as speech style cannot be controlled for. Another circumstance that may make the application of (25) difficult is fixed stress. If accented syllables are always word-initial, as in Bengali, for instance, any phonetic differences between a deaccented syllable and any other lexically unaccented syllable can in principle be attributed to word-initial effects on duration and articulatory precision (Keating et al. 2003), rather than to the fact that

11 More recently, greater spectral tilt, a larger decrease in intensity towards the higher frequency end of the spectrum, has been found in unstressed syllables in Dutch (Sluijter 1995, Sluijter \& van Heuven 1996). This difference, too, correlates with stress in languages other than Dutch (e.g. Crosswhite 2003). 


\section{Carlos Gussenhoven}

the representation before deaccenting had an accent on that syllable. Tokyo Japanese has morphological and phrasal rules deleting accents (Poser 2001), but the issue of neutralisation has not been explicitly addressed in a perception experiment. On the basis of the negligible differences in duration and intensity between accented and unaccented syllables (Beckman 1986), Japanese deaccenting is almost certainly neutralising. Although there may be further phonetic measures to be investigated, like spectral tilt, Nubi deaccenting, too, is neutralising. Outside accented syllables there is only one type of prosodic syllable, and the members of accentual minimal pairs are homophonous when deaccented. Thus, while Nubi has the hallmarks of a stress-accent language in having obligatory, culminative prominence, it cannot be said to be a typical 'stress language'.

\subsection{Intonation}

There is a further characteristic of stress-accent languages that Beckman (1986: 1) mentions: 'the pitch shape of the accentual pattern [of stress accent] cannot be specified in the lexicon but rather is chosen for a specific utterance from an inventory of shapes provided by the intonation system'. In Nubi there is no choice from a paradigm of tones (or 'pitch accents' in the sense of Pierrehumbert 1980), and sentences have 'invariant tonal contours' (cf. Hayes 1995: 49-50). Thus, the H tone that is introduced in accented syllables cannot meaningfully be said to be an 'intonational tone'. Given a sentence, its tonal structure is determined by the words in it, and no structural variation is allowed outside a choice of the final boundary tone.

As shown in $\$ 4.2$, there is one respect in which Nubi sentence prosody resembles that of European stress-accent languages. A postlexical feature that may distinguish stress accent from tone is the ability of the prominent syllable to undergo a 'shift' to a domain-initial position. A rhythm rule of the type exemplified by English SWEET sixTEEN vs. SIXteen SWEETS puts the accent in English in the metrical camp simply by virtue of displaying this kind of clash resolution. Tone may be attracted leftward by stressed syllables, but the distance is typically a single syllable. The latter phenomenon is best seen as leftward tone spreading; similarly, Meeussen's Rule, whereby a $\mathrm{H}$ is deleted before another $\mathrm{H}$, is to be interpreted as dissimilation rather than clash resolution (Hyman 2004). Like the English Rhythm Rule (Selkirk 1984, Gussenhoven 2005), Nubi Accent Shift results from the alignment of accents with the edges of the phonological phrase, as shown in $\$ 4$.

\section{Nubi as a typological pivot}

Nubi has obligatory, culminative, metrically bound accent, with only a single tone being inserted in the accent locations. Since the inserted 
tone does not contrast with any other tone, it does not define the phonological shape of the word, nor does it define a discourse meaning. Given the appearance in surface structure of accents that have survived morphological and postlexical deletions and insertions, the presence of the tone is predictable. The language thus occupies a space in between the major word-prosodic typological classes of tone languages and stressaccent languages. If 'pitch-accent languages' are recognised as a separate class, having maximally one invariant tone or tone sequence per word-like constituent (cf. Japanese, Northern Bizkaian Basque), then Nubi fits that description, too, but differs from these oft-cited cases in having this tone in all words. This 'obligatoriness' rather puts it in the camp of stress-accent languages.

By definition (22) (Hyman 2001, 2006), Nubi is a tone language. A definition of the notion 'tone language' that excludes Nubi would be one in which the requirement that the phonological specification of morphemes must include a specification of pitch is restricted to cases in which minimally one of the following aspects is not predictable from the phonological representation: (a) the identity of the morphemes so marked, (b) the specific pitch feature that is marked or (c) the location of the pitch feature (cf. §6.1). Without this clause, Nubi is a tone language, as well as a stress-accent language and a pitch-accent language.

Our discussion of Nubi has yielded an alternative definition of the stress-accent $v s$. non-stress-accent distinction. The criterion whether a prosodic distinction exists among unaccented syllables (cf. (25)) is structural (phonological) rather than phonetic. In $\$ 6.2$, the criterion was argued to be inapplicable to languages that never deaccent (because without deaccented syllables around, no comparison can be made with syllables that never had accent), and to languages that, like Bengali, have fixed, word-peripheral stress (because with all deaccented syllables being word-peripheral, any differences between deaccented and unaccented syllables can be attributed to word-peripherality). Languages like Bengali are indeterminate with respect to (25); they may of course vary in the extent to which other phonetic features than pitch are involved in marking word-level prominence, as indeed will be the case for languages in which deaccenting is non-neutralising.

\section{Appendix}

Ten speakers made minidisk recordings at the Nubi Cultural Centre in Bombo of a corpus of 160 brief sentences and words. 64 of these were designed to elicit four verb forms in pre-final sentential position, viz. the stem, gerund, Wellens' infinitive and the passive, of 16 verbs or verbal adjectives: monosyllabic/já/, /só/ and /gúm/, disyllabic /fáta/, /sídu/, /júru/,/nadí/, /wedí/ and/tabán/, and trisyllabic /béredu/, /kásulu/, /séregu/, /jaríbu/, /nesítu/, /pangísa/ and/fatarán/. Between them, these stems represent all possible accent positions and final syllable types. In addition, sentence-final and isolated pronunciations of the stem, gerund 


\section{Carlos Gussenhoven}

and passive of the same verbs were elicited, yielding another 96 expressions. In the course of the recordings, a number of modifications were made in this corpus, on the basis of speaker preferences. A technical problem caused the recordings of four speakers and part of the recordings of a fifth speaker to be lost. Of the remaining material, not all utterances were useable, either because of background noise or speaker disfluency. Comparisons of acoustic measures are always between means over equivalent sets of forms. Since in many cases no recordings were available of all relevant forms by all speakers, the number of speakers involved in these comparisons varies. Segmentation was performed by inspecting the speech waveform, while drawing on spectral and auditory information where desirable. The boundary between [w] and [e] in /wedi/ was located halfway along the fairly steep F2 transition. The duration of the word-initial consonants in disyllables has been left out of consideration, because it was impossible to establish the beginning of [f] in /fata/ in a number of cases, its friction being indistinguishable from background noise. For this reason, the duration of word-initial consonants in disyllables was not considered in Fig. 3. Similarly, the beginning of the wordinitial voiceless plosives in / kasulu/, /pangisa/ could not be established, either because they were utterance-initial or occurred after pause. Since it was undesirable to disregard word-internal coda and onset-consonant durations, syllable durations are reported in the case of the trisyllabic words in Fig. 8, where the beginning of word-initial syllables with voiceless plosive onsets was taken to be the release of the plosive. Since all comparisons are between means over identical segmental and speaker conditions, no biases arise from any of these segmentation criteria.

All effects are reported as significant at $\mathrm{p}>0 \cdot 5$, and are Huynh-Feldt corrected.

\section{REFERENCES}

Beckman, Mary E. (1986). Stress and non-stress accent. Dordrecht: Foris.

Berinstein, Ava E. (1979). A cross-linguistic study on the perception and production of stress. UCLA Working Papers in Phonetics 47. 1-59.

Bruce, Gösta (1977). Swedish word accents in sentence perspective. Lund: Gleerup.

Cambier-Langeveld, Tina \& Alice E. Turk (1999). A cross-linguistic study of accentual lengthening: Dutch vs. English. FPh 27. 255-280.

Clements, G. N. (1993). Lieu d'articulation des consonnes et des voyelles: une théorie unifiée. In Bernard Laks \& Annie Rialland (eds.) Architecture des répresentations phonologiques. Paris: CNRS. 101-145.

Crosswhite, Katherine (2003). Spectral tilt as a cue to word stress in Polish, Macedonian, and Bulgarian. In M. J. Solé, D. Recasens \& J. Romero (eds.) Proceedings of the 15th International Congress of Phonetic Sciences. Barcelona: Causal Productions. 767-770.

de Jong, Kenneth \& Bushra Adnan Zawaydeh (1999). Stress, duration, and intonation in Arabic word-level prosody. $\mathscr{F P h ~ 2 7 . ~ 3 - 2 2 . ~}$

Dogil, Grzegorz \& Briony Williams (1999). The phonetic manifestation of word stress. In van der Hulst (1999b). 273-334.

Donohue, Mark (1997). Tone systems in New Guinea. Linguistic Typology 1. 347-386. Elordieta, Gorka (1997). Accent, tone and intonation in Lekeitio Basque. In Fernando Martínez-Gil \& Alfonso Morales-Front (eds.) Issues in the phonology and morphology of the major Iberian languages. Washington, D.C.: Georgetown University Press. 34-78. 
Elordieta, Gorka (1998). Intonation in a pitch accent variety of Basque. Anuario del Seminario de Filología Vasca 'Fulio de Urquijo' [International Fournal of Basque Linguistics and Philology] 32. 511-569.

Goldsmith, John A. (1976). Autosegmental phonology. PhD dissertation, MIT. Published 1979, New York: Garland.

Gomez-Imbert, Elsa \& Michael Kenstowicz (2000). Barasana tone and accent. IFAL 66. 419-463.

Gussenhoven, Carlos (1983). Focus, mode and the nucleus. $\mathscr{F L}$ 19. 377-417. Reprinted in Gussenhoven (1984).

Gussenhoven, Carlos (1984). On the grammar and semantics of sentence accents. Dordrecht: Foris.

Gussenhoven, Carlos (1991). The English Rhythm Rule as an accent deletion rule. Phonology 8. 1-35.

Gussenhoven, Carlos (1992). Sentence accents and argument structure. In Iggy Roca (ed.) Thematic structure: its role in grammar. Berlin \& New York: Foris. 79-106.

Gussenhoven, Carlos (2004). The phonology of tone and intonation. Cambridge: Cambridge University Press.

Gussenhoven, Carlos (2005). Procliticized phonological phrases in English: evidence from rhythm. Studia Linguistica 59. 174-193.

Gussenhoven, Carlos \& Jörg Peters (2004). A tonal analysis of Cologne Schärfung. Phonology 21. 251-285.

Gussenhoven, Carlos \& Natasha Warner (eds.) (2002). Laboratory Phonology 7. Berlin $\&$ New York: Mouton de Gruyter.

Halle, Morris \& Jean-Roger Vergnaud (1987). An essay on stress. Cambridge, Mass.: MIT Press.

Hayes, Bruce (1995). Metrical stress theory: principles and case studies. Chicago: University of Chicago Press.

Heine, Bernd (1982). The Nubi language of Kibera: an Arabic creole. Grammatical sketch and vocabulary. Vol. 3 of Bernd Heine \& Wilhelm J. G. Möhlig (eds.) Language and dialect atlas of Kenya. Berlin: Reimer.

Hellmuth, Sam (2005). Cause for concern in Cairo: why we should describe Arabic intonation. Paper presented at the workshop 'Making Sense of Prosody', SOAS, London.

Hermans, Ben (1985). Het Limburgs en het Litouws als metrisch gebonden toontalen. Spektator 14. 48-70.

Hermes, Dik J. \& Joost C. van Gestel (1991). The frequency scale of speech intonation. FASA 90. 97-102.

Hualde, José Ignacio (1999). Basque accentuation. In van der Hulst (1999b). 947-993.

Hualde, José Ignacio, Gorka Elordieta, Iñaki Gaminde \& Rajka Smiljanić (2002). From pitch-accent to stress-accent in Basque. In Gussenhoven \& Warner (2002). 547-584.

Hulst, Harry van der (1999a). Word accent. In van der Hulst (1999b). 3-115.

Hulst, Harry van der (ed.) (1999b). Word prosodic systems in the languages of Europe. Berlin \& New York: Mouton de Gruyter.

Hyman, Larry M. (1981). Tonal accent in Somali. Studies in African Linguistics 12. 169-203.

Hyman, Larry M. (2001). Tone systems. In Martin Haspelmath, Ekkehard König, Wulf Oesterreicher \& Wolfgang Raible (eds.) Language typology and language universals: an international handbook. Vol. 2. Berlin \& New York: de Gruyter. 1367-1380.

Hyman, Larry M. (2004). Universals of tone rules: thirty years later. Paper presented at the International Conference on Tone and Intonation, Santorini, Greece. To 


\section{Carlos Gussenhoven}

appear in Tomas Riad \& Carlos Gussenhoven (eds.) Tones and tunes. Vol. 1: Typological and comparative studies in word and sentence prosody. Berlin \& New York: Mouton de Gruyter.

Hyman, Larry M. (2006). Word-prosodic typology. Phonology 23. 225-257 (this issue).

Kager, René (1999). Optimality Theory. Cambridge: Cambridge University Press.

Keating, Patricia, Taehong Cho, Cécile Fougeron \& Chai-Shune Hsu (2003). Domain-initial articulatory strengthening in four languages. In John Local, Richard Ogden \& Rosalind Temple (eds.) Phonetic interpretation: papers in laboratory phonology VI. Cambridge: Cambridge University Press. 145-163.

Kiparsky, Paul (1982). From cyclic to lexical phonology. In Harry van der Hulst \& Norval Smith (eds.) The structure of phonological representations. Part 1. Dordrecht: Foris. 131-175.

Kristoffersen, Gjert (2000). The phonology of Norwegian. Oxford: Oxford University Press.

Kubozono, Haruo (1993). The organization of Fapanese prosody. Tokyo: Kurosio.

Ladd, D. Robert (1996). Intonational phonology. Cambridge: Cambridge University Press.

Levi, Susannah V. (2005). Acoustic correlates of lexical accent in Turkish. Fournal of the International Phonetic Association 35. 73-97.

Liberman, Mark \& Alan Prince (1977). On stress and linguistic rhythm. LI 8. 249-336.

Luffin, Xavier (2005). Un créole arabe : le kinubi de Mombasa, Kenya. Munich: Lincom Europa.

Nespor, Marina \& Irene Vogel (1986). Prosodic phonology. Dordrecht: Foris.

Owens, Jonathan (1977). Aspects of Nubi syntax. PhD thesis, SOAS, London.

Owens, Jonathan (1980). Monogenesis, the universal and the particular in Creole studies. Anthropological Linguistics 22. 97-117.

Owens, Jonathan (1996). Arabic-based pidgins and creoles. In Sarah G. Thomason (ed.) Contact languages : a wider perspective. Amsterdam \& Philadelphia: Benjamins. 125-172.

Pierrehumbert, Janet B. (1980). The phonology and phonetics of English intonation. PhD dissertation, MIT. Published 1990, New York: Garland.

Pierrehumbert, Janet B. \& Mary E. Beckman (1988). Fapanese tone structure. Cambridge, Mass. : MIT Press.

Poser, William J. (2001). The phonetics and phonology of tone and intonation in Fapanese. Stanford: CSLI. PhD dissertation, MIT, 1984.

Remijsen, Bert (2002). Lexically contrastive stress accent and lexical tone in Ma'ya. In Gussenhoven \& Warner (2002): 585-614.

Roca, Iggy (2005). Saturation of parameter settings in Spanish stress. Phonology 22. 343-392.

Selkirk, Elisabeth (1980). The role of prosodic categories in English word stress. LI 11. 563-605.

Selkirk, Elisabeth (1984). Phonology and syntax: the relation between sound and structure. Cambridge, Mass.: MIT Press.

Selkirk, Elisabeth (1986). On derived domains in sentence phonology. Phonology Yearbook 3. 371-405.

Selkirk, Elisabeth (1995). Sentence prosody: intonation, stress, and phrasing. In John A. Goldsmith (ed.) The handbook of phonological theory. Cambridge, Mass. \& Oxford: Blackwell. 550-569.

Selkirk, Elisabeth (2000). The interaction of constraints on prosodic phrasing. In Merle Horne (ed.) Prosody : theory and experiment. Studies presented to Gösta Bruce. Dordrecht: Kluwer. 231-261. 
Between stress and tone in Nubi word prosody 223

Sluijter, Agaath M. C. (1995). Phonetic correlates of stress and accent. The Hague: Holland Academic Graphics.

Sluijter, Agaath M. C. \& Vincent J. van Heuven (1996). Spectral balance as an acoustic correlate of linguistic stress. F ASA 100. 2471-2485.

Voorhoeve, Jan (1973). Safwa as a restricted tone system. Studies in African Linguistics 4. 1-21.

Wellens, Ineke (2005). The Nubi language of Uganda: an Arabic creole in Africa. Leiden \& Boston: Brill. 